\title{
COMPARATIVE STUDY - OUTCOME OF SUBTOTAL THYROIDECTOMY VS TOTAL THYROIDECTOMY FOR MULTINODULAR GOITRE
}

\author{
M. R. Madan Karthik Raj ${ }^{1}$, Akmal ${ }^{2}$ \\ ${ }_{1}^{1}$ Assistant Professor, Department of Surgery, Vinayaka Mission's Kirupanandha Variyar Medial College, Salem. \\ 2Junior Resident, Department of Surgery, Vinayaka Mission's Kirupanandha Variyar Medical College, Salem.
}

\begin{abstract}
BACKGROUND

Multinodular Goitre (MNG) comprises a spectrum of clinical features, consists of multiple hyper-functioning nodules scattered throughout an enlarged thyroid gland that also may contain non-functioning nodules. Medical care or radioactive iodine may be used for larger goitres; but the best choice of MNG treatment is surgery, especially in cosmetic problem, compressive symptom, toxicity and suspicion of malignancy. There are several methods for thyroid gland operation such as Subtotal Thyroidectomy (STT), NearTotal Thyroidectomy (NTT), hemi-thyroidectomy plus subtotal resection (Dunhill procedure) and Total Thyroidectomy (TT). But the surgical method of benign thyroid disease treatment is still controversial.
\end{abstract}

\section{AIMS AND OBJECTIVES}

To assess the clinical profile of multinodular goitre and to assess and compare the outcome of subtotal and total thyroidectomy for the patients of multinodular goitre.

\section{MATERIALS AND METHODS}

A prospective interventional study was done at Vinayaka Mission's Kirupananda Variyar Medical College and Hospital during the period of August 2013 - August 2015. A non-random purposive sampling was done and 40 cases were selected as the study population. All the patients were diagnosed as multinodular goitre by doing FNAC. Patients with thyroid malignancy were excluded from the study. All patients were rendered euthyroid before surgery. Among 40 patients 20 patients had undergone subtotal thyroidectomy and the remaining 20 patients had undergone total thyroidectomy. All the patients were followed up over a period of 1 year.

\section{RESULTS}

The mean thyroid and calcium levels were almost in the normal limits for all the patients, both in the preoperative phase as well as in the postoperative period. Among the patients who had undergone total thyroidectomy only one patient had developed the complications of recurrent laryngeal nerve injury, superior laryngeal nerve injury, hypothyroidism and hypoparathyroidism, whereas among the patients who underwent subtotal thyroidectomy none of these complications were seen; 3 patients out of 20 who had undergone subtotal thyroidectomy had developed recurrence at the end of 1 year, whereas there was no evidence of recurrence among the patients who had undergone total thyroidectomy and the difference was found to be statistically significant $(\mathrm{p}<.0001)$.

\section{CONCLUSION}

Despite the higher rate of post-operative complications, total thyroidectomy will be more beneficial in the surgical treatment of benign thyroid disorders.

\section{KEYWORDS}

Multinodular Goitre, Subtotal Thyroidectomy, Total Thyroidectomy.

HOW TO CITE THIS ARTICLE: Raj MRMK, Akmal. Comparative study - outcome of subtotal thyroidectomy vs total thyroidectomy for multinodular goitre. J. Evolution Med. Dent. Sci. 016;5(46):2848-2854, DOI: 10.14260/jemds/2016/665

\section{INTRODUCTION}

Multinodular thyroid enlargement is a symptom of different thyroid diseases of various aetiology. There are two different types of epidemiological characteristics of goitres like endemic and sporadic goitres. Goitre endemic is assessed by definition in regions with a prevalence of more than $10 \%$ among the population under investigation. ${ }^{1}$ In most endemic areas, iodine deficiency and intake of goitrogens via water and foodstuffs are the most important causes of the goitre. Vegetables with

Financial or Other, Competing Interest: None.

Submission 09-05-2016, Peer Review 22-05-2016,

Acceptance 24-05-2016, Published 07-06-2016.

Corresponding Author:

Dr. M. R. Madan Karthik Raj,

24 B Shri Saraswathi Apartments, Ramakrishna Road,

Opposite to GOPI Hospital,

Salem-636007.

E-mail:drmkraja@gmail.com

DOI: $10.14260 /$ jemds/2016/665 goitrogenic effect contain thioglycosides or cyanogenic glycosides. ${ }^{2}$ In this context, cigarette smoking is thought to be a cofactor for goitrogenesis, since it increases serum thiocyanate concentration.

Regions with iodine deficiency and endemic goitre are found all over the world, particularly in mountainous areas and continental regions, where iodine prophylaxis is not used.1,3 Multinodular Goitre (MNG) comprises a spectrum of clinical features, consists of multiple hyper-functioning nodules scattered throughout an enlarged thyroid gland that also may contain non-functioning nodules. ${ }^{4}$ Using ultrasonography in an area with borderline iodine deficiency, MNG is found in approximate $23 \%$ of the general population. ${ }^{5}$ Medical care or radioactive iodine may use for larger goitres, but the best choice of MNG treatment is surgery, especially in cosmetic problem, compressive symptom, toxicity and suspicion of malignancy. ${ }^{6}$ There are several methods for thyroid gland operation such as Subtotal Thyroidectomy 
(STT), Near-Total Thyroidectomy (NTT), hemi-thyroidectomy plus subtotal resection (Dunhill procedure) and Total Thyroidectomy (TT).

But the surgical method of benign thyroid disease treatment is still controversial.6,7 Before 20th century, the risks associated with major surgery for treating thyroid diseases and the problems of adequate hormonal replacement had deterred surgeons from performing total thyroidectomy, and in fact, this method, was only performed occasionally for thyroid cancers. 8,9 Nowadays, the use of total thyroidectomy, which is designed to remove whole thyroid tissue, remains controversial for small differentiated thyroid carcinomas, but even more controversial is its use to treat benign diseases. ${ }^{10,11}$ The major complications related to total thyroidectomy are permanent hypoparathyroidism and recurrent laryngeal nerve injuries. ${ }^{12}$ Also there are several studies, which have showed that the complication rates of permanent recurrent laryngeal nerve palsy $(0-1.3 \%)$ and permanent hypoparathyroidism (0.5-1\%) following subtotal thyroidectomy are similar to those following total thyroidectomy. ${ }^{13-17}$

Other disadvantages of subtotal thyroidectomy for treating multinodular goitres are that the procedure does not reduce the risk of persisting symptoms and has a high recurrence rate $(30-50 \%)$ owing to gland remnants. ${ }^{18,19}$ The aim of a surgeon performing Subtotal and Near Total Thyroidectomy (STT and NTT) for MNG is to try to keep the patient euthyroid postoperatively avoiding the need for lifelong thyroid replacement. But despite of the little remnant thyroid tissue in all surgical procedures, except of total thyroidectomy, the necessity of treatment with thyroid hormone still remains. ${ }^{20}$ In this context, this present study was designed to compare and assess the clinical profile and the outcomes of two types of surgical interventions for goitre.

\section{AIMS AND OBJECTIVES}

1. To assess the clinical profile of multinodular goitre patients attending surgical op during.

2. To compare the outcomes of two types of surgical methods (Subtotal and total thyroidectomy) among patients with multinodular goitre.

\section{MATERIALS AND METHODS}

The study was done as a hospital-based prospective study during the period of two years August 2013 - August 2015 in VMKVMC, Salem, among the diagnosed multinodular goitre adult patients randomly selected in the surgical outpatient department after applying inclusion and exclusion criteria. A total of 40 cases have been randomly selected for the study.

\section{Inclusion Criteria}

- $\quad$ Age group $>18$ years.

- All patients with final pathologic diagnosis consistent with multinodular goitre.

- Patients who gave consent for surgery.

\section{Exclusion Criteria}

- Age group $<18$ years.

- Previously known thyroid malignancy.

- Final pathologic process containing thyroid neoplasm requiring complete thyroidectomy.

- $\quad$ Patient not giving consent for surgery.

\section{Statistical Analysis}

Data were entered in SPSS version 17. The parametric variables were analysed by using ' $t$ ' test and all the nonparametric variables were analysed by using chi-square test. $P$ value $<.05$ was considered as statistically significant.

\section{Routine Investigations done on the Patients}

$\mathrm{Hb}, \mathrm{TC}, \mathrm{DC}, \mathrm{ESR}, \mathrm{BT}$ and CT

Blood sugar

Blood urea, creatinine

ECG

Echo

\section{Special Investigations done on the Patients}

- $\quad$ Thyroid function test - Free T3, Free T4 and TSH.

- FNAC - Fine Needle Aspiration Cytology.

- Serum Calcium.

- Indirect Laryngoscopy.

\section{OPERATIVE PROCEDURE}

\section{Preoperative Measures}

All patients were rendered euthyroid before surgery. Preoperative preparation of patients with thyrotoxicosis is particularly critical to avoid operative or postoperative thyroid storm. The planned procedure was discussed with the patient and informed consent was obtained. The tentative skin incision is marked preoperatively using a permanent marker pen on the awake patient with reclined neck. This is done in a symmetric fashion along the Langer's skin lines or in a skin crease in between the medial borders of the sternocleidomastoid muscles. The appropriate position of the neck incision is approximately two finger breadths above the sternal notch or in the middle between the sternal notch and the thyroid cartilage.

\section{Positioning and Draping}

The patient is positioned with the neck extended. Rolled towels are placed under the shoulders which allow sufficient neck extension. A sponge doughnut is placed under the occiput for adequate head support. In order to prevent venous congestion in the neck, the head of the table is elevated to a $30^{\circ}$ position during surgery. Disinfection is performed using an alcoholic agent without iodine, which might interfere with postoperative radionuclear scanning and ablative therapy.

\section{Skin Incision and Creation of Skin Flaps}

A curvilinear collar-type incision is placed transversally along the Langer's line of the skin, i.e. the standard Kocher's incision. The use of a natural skin crease if present seems attractive. In order to optimize cosmesis, the skin incision should be as long as necessary but as short as possible. It is believed that a 4- to $5-\mathrm{cm}$ incision allows safe thyroidectomy in most cases and results in excellent cosmesis. The incision is carried out through the skin and the subcutaneous layer through the platysma muscle to the lateral extent of the skin incision. The two skin flaps are created by dissecting them away from the strap muscles upward to the thyroid cartilage and downward to the sternal border. Elevation of the two flaps is almost bloodless if the layer beneath the platysma is followed and dissected. 


\section{Strap Muscles}

The approach to the thyroid capsule is done by splitting the strap muscles in the midline. Small crossing vessels are treated with bipolar coagulation. For a bilateral approach, the left thyroid lobe is first dissected. By predominantly blunt dissection, the anterior aspect of the respective thyroid gland is exposed. Caution was applied while retracting the strap muscles to avoid disrupting the medial thyroid veins.

\section{Upper Pole}

Using Kocher's forceps, lateral retraction of the upper pole of the thyroid lobe is applied in order to open up the avascular space between the lobe and the cricothyroid muscle, thus exposing the external branch of the superior laryngeal nerve. This nerve can sometimes be identified as it descends with the vessels and anterior to the cricoid muscle, but is often not visible.

\section{Hilum of the Gland \\ Capsular dissection, as described by Thompson et al, ${ }^{21}$ refers to the development of a plane between the thyroid capsule and the tertiary branches of the inferior thyroid artery. The branches are ligated or clipped individually directly on the surface of the thyroid gland. This method minimizes the surgical damage to both the parathyroid glands and the RLN. The nerve was easily found at its constant landmark, the so- called Zuckerkandl tuberculum, where it crosses beneath the thyroid gland and enters below Berry's ligament of the thyroid cartilage.}

\section{Handling of the Parathyroid Glands}

Regardless of whether a unilateral lobectomy or total thyroidectomy is performed, all identified parathyroid tissue should be preserved on its native blood supply. The best way to preserve the parathyroid glands in situ is the extracapsular dissection of the thyroid gland. With the utilization of the extracapsular dissection, the parathyroid glands are swept off the thyroid capsule and are left in situ with their vascular pedicles.

\section{Lower Thyroid Pole}

The transection of the vessels running to the lower pole is usually done after proper exposition of the RLN. Veins from the anterior superior mediastinum are exposed and divided very close to the thyroid gland.

\section{Removal of the Lobe}

During the final steps of the thyroidectomy, the lobe is dissected away from the trachea under constant exposure and preservation of the RLN. The dense attachments at the level of the posterior suspensory ligament (Berry) usually require sharp dissection. Attention must then be paid to the relatively constant superior branch of the inferior thyroid artery (Criminal branch) that often crosses underneath the RLN and spreads medially from beneath the nerve into the thyroid gland. The use of any cautery or other thermal dissection device should be avoided at this step due to the potential for thermal injury of the RLN that is in close proximity to the inferior thyroid artery. Inadvertent bleeding from this artery and uncontrolled attempts of haemostasis at this point of dissection may harm the RLN. Sudden bleeding is best handled with the aid of suction by identifying the vessel stump and clamping or clipping, being constantly aware of the presence of the RLN. If oozing occurs at this point, the placement of a haemostatic gelatine sponge is advised.

\section{Wound Closure}

The strap muscles are sutured continuously with a 3-0 absorbable thread, the platysma with a 4-0 thread and the skin is closed by an intradermal running suture using 5-0 absorbable thread. A smooth collar may be used for the first 24 hours postoperatively and the patient was advised to keep a head up position of about $30^{\circ}$ in order to minimize venous congestion and swelling of the soft tissues around the wound.

\section{RESULTS}

The mean age of the study population was 51.62 and the majority (55\%) belong to 51-55 years of age. Among the study participants, $75 \%$ were females with the female-to-male ratio was $3: 1$ and $12.5 \%$ of the patients had a strong family history of goitre. The mean size of the goitre among the patients was $6.9 \times 6.4 \mathrm{~cm}$. Among the study participants $17.5 \%$ of the patients the border was well defined and for the remaining $82.5 \%$ it was a diffuse swelling. Ten percentage of the patients showed shift of trachea towards right side, whereas the remaining showed trachea in midline. (Table - 1) The mean and SD of the thyroid parameters and the serum calcium levels among the study population before thyroidectomy were within normal limits. The thyroidectomy surgery was undertaken only after making the patients to the euthyroid state. In our study, all the patients who were operated for MNG were all in the euthyroid condition.

In this study, it is depicted that $50 \%$ of the people had undergone subtotal thyroidectomy and the remaining 50\% had undergone total thyroidectomy. The types of surgery for the patients were decided based on their willingness and consent. Table 2 shows the mean and SD of the thyroid profile parameters and the serum calcium levels among the patients who underwent subtotal thyroidectomy. It is inferred from the table that the mean levels of all the thyroid parameters and the serum calcium levels were all in the range of the normal values. Similarly, the mean and SD of the thyroid profile parameters and the serum calcium levels among the patients who underwent total thyroidectomy were also within normal limits. The comparison of thyroid profile parameters and the serum calcium levels among the patients who underwent subtotal and total thyroidectomy in the Table 2 showed that except the free T3 levels all the other serological parameters were almost similar in both the groups with no significant difference between them.

The mean free T3 level was found to be slightly lower in the total thyroidectomy group, as one patient had developed hypothyroidism in that group. Table 3 shows the postoperative complications among the patients who underwent subtotal and total thyroidectomy. It is inferred from the table that among the patients who had undergone total thyroidectomy only one patient had developed the complications of recurrent laryngeal nerve injury, superior laryngeal nerve injury, hypothyroidism and hypoparathyroidism, whereas among the patients who underwent subtotal thyroidectomy none of these complications were seen. These were the common complications occurred in total thyroidectomy based on the literature review. Table 4 shows the incidence of recurrence of goitre among the study population at the end of 1 year. It is 
depicted from the table that 3 patients out of 20 who had undergone subtotal thyroidectomy had developed recurrence at the end of 1 year, whereas there was no evidence of recurrence among the patients who had undergone total thyroidectomy and this difference was found to be statistically significant $(\mathrm{p}<.0001)$.

\section{DISCUSSION}

MNG is a common endocrine disorder in the world. It can give rise to complications like local compression effects, development of toxicity and malignant transformation. As there is no standard treatment for MNG, regional trends influence the treatment. ${ }^{22}$ The present study has brought forth many significant points. The incidence of MNG among thyroid diseases has been $11.2-73.3 \% .{ }^{23}$ Chellum et al24 and 0sime. ${ }^{25}$ have observed that thyroid diseases are common fourth decade of life. In the present study, fourth decade has the highest number of MNG cases. The mean age of MNG in the present study has been $51.6 \pm 8.64$ years and were consistent with many studies as shown in Table 5.

\begin{tabular}{|c|c|}
\hline Variables & Frequency \\
\hline $\begin{array}{l}\text { Age Group } \\
\qquad \begin{array}{r}41-45 \text { years } \\
46-50 \text { years } \\
51-55 \text { years } \\
56-60 \text { years }\end{array}\end{array}$ & $\begin{array}{c}3(7.5 \%) \\
10(25 \%) \\
22(55 \%) \\
05(12.5 \%)\end{array}$ \\
\hline Gender & $\begin{array}{l}10(25 \%) \\
30(75 \%)\end{array}$ \\
\hline $\begin{array}{c}\text { Family history of goitre } \\
\text { Positive } \\
\text { Negative } \\
\end{array}$ & $\begin{array}{l}05(12.5 \%) \\
35(87.5 \%) \\
\end{array}$ \\
\hline $\begin{array}{c}\text { Size of the goitre } \\
\text { Mean vertical diameter } \\
\text { Mean horizontal diameter }\end{array}$ & $\begin{array}{l}6.9(1.60) \\
6.4(1.01)\end{array}$ \\
\hline $\begin{array}{c}\text { Border of the goitre } \\
\text { Well defined } \\
\text { Diffuse }\end{array}$ & $\begin{array}{l}07(17.5 \%) \\
33(82.5 \%)\end{array}$ \\
\hline $\begin{array}{c}\text { Position of Trachea } \\
\text { Midline } \\
\text { Shift to right } \\
\end{array}$ & $\begin{array}{l}36(90 \%) \\
04(10 \%)\end{array}$ \\
\hline $\begin{array}{l}\text { Type of surgery } \\
\text { Subtotal thyroidectomy } \\
\text { Total thyroidectomy }\end{array}$ & $\begin{array}{l}20(50 \%) \\
20(50 \%)\end{array}$ \\
\hline $\begin{array}{l}\text { Table 1: Frequency Di } \\
\text { Participants in Relatio }\end{array}$ & $\begin{array}{l}\text { he Study } \\
\text { ariables }\end{array}$ \\
\hline
\end{tabular}

\begin{tabular}{|c|c|c|c|}
\hline \multirow{2}{*}{$\begin{array}{l}\text { Thyroid } \\
\text { profile } \\
\text { and Sr. } \\
\text { Calcium }\end{array}$} & \multicolumn{2}{|c|}{ Mean Values } & \multirow[b]{2}{*}{$\begin{array}{c}P \\
\text { value }\end{array}$} \\
\hline & $\begin{array}{c}\text { Subtotal } \\
\text { Thyroidectomy }\end{array}$ & $\begin{array}{c}\text { Total } \\
\text { Thyroidectomy }\end{array}$ & \\
\hline $\begin{array}{l}\text { Free T3 } \\
\text { (ng/dL) }\end{array}$ & 5.84 & 4.94 & 0.026 \\
\hline $\begin{array}{l}\text { Free T4 } \\
(\mathrm{ng} / \mathrm{dL}) \\
\end{array}$ & 11.78 & 11.21 & 0.351 \\
\hline $\begin{array}{c}\text { TSH } \\
(\mathrm{ng} / \mathrm{dL})\end{array}$ & 4.12 & 4.74 & 0.322 \\
\hline $\begin{array}{c}\text { Sr. } \\
\text { Calcium } \\
(\mathrm{mg} / \mathrm{dL})\end{array}$ & 9.60 & 9.41 & 0.535 \\
\hline \multicolumn{4}{|c|}{$\begin{array}{c}\text { Table 2: Comparison of Mean of Thyroid Profile and } \\
\text { Serum Calcium Levels among the Patients who } \\
\text { Underwent Subtotal Thyroidectomy and Total } \\
\text { Thyroidectomy }\end{array}$} \\
\hline
\end{tabular}

$P$ value derived by applying unpaired T test

\begin{tabular}{|c|c|c|c|}
\hline $\begin{array}{l}\text { Post-operative } \\
\text { Compli-cations }\end{array}$ & $\begin{array}{l}\text { Subtotal } \\
\text { Thyroi- } \\
\text { dectomy }\end{array}$ & $\begin{array}{c}\text { Total } \\
\text { Thyroi- } \\
\text { dectomy }\end{array}$ & $\begin{array}{c}P \\
\text { value }\end{array}$ \\
\hline $\begin{array}{l}\text { Recurrent } \\
\text { laryngeal nerve } \\
\text { injury }\end{array}$ & 0 & $1(5 \%) / 20$ & 0.0241 \\
\hline $\begin{array}{l}\text { Superior laryngeal } \\
\text { nerve injury }\end{array}$ & 0 & $1(5 \%) / 20$ & 0.0241 \\
\hline Hypothyroidism & 0 & $1(5 \%) / 20$ & 0.0241 \\
\hline $\begin{array}{l}\text { Hypo- } \\
\text { parathyroidism }\end{array}$ & 0 & $1(5 \%) / 20$ & 0.0241 \\
\hline \multicolumn{4}{|c|}{$\begin{array}{c}\text { Table 3: Postoperative Complications among the } \\
\text { Patients who Underwent Subtotal and Total } \\
\text { Thyroidectomy }\end{array}$} \\
\hline
\end{tabular}

$\mathrm{P}$ value derived by applying Chi-square test with Yates correction.

\begin{tabular}{|c|c|c|c|}
\hline $\begin{array}{c}\text { Recurrence } \\
\text { of Goitre }\end{array}$ & $\begin{array}{c}\text { Subtotal } \\
\text { Thyroidectomy }\end{array}$ & $\begin{array}{c}\text { Total } \\
\text { Thyroidectomy }\end{array}$ & $\begin{array}{c}\text { P } \\
\text { value }\end{array}$ \\
\hline Present & 3 & 0 & \multirow{2}{*}{$<.001$} \\
\hline Absent & 17 & 20 & \\
\cline { 1 - 3 } Total & $\mathbf{2 0}$ & $\mathbf{2 0}$ & \\
\cline { 1 - 3 } Table 4: Incidence of Recurrence of Goitre among the \\
Study Population at the End of 1 Year \\
\hline
\end{tabular}

$\mathrm{P}$ value derived by applying Chi-square test with Yates correction.

\begin{tabular}{|c|c|}
\hline Study & Mean Age in Years \\
\hline Abu-Eshy et al ${ }^{26}$ & $37.7 \pm 14.3$ \\
\hline Koh and Chang $27^{27}$ & 35.7 \\
\hline${\text { Delbridge et } \mathrm{al}^{28}}^{29}$ & $53.0 \pm 14$ \\
\hline Korun et al $^{29}$ & $43.6 \pm 9.7$ \\
\hline${\text { Marchesi et } \mathrm{al}^{30}}^{\text {Present study }}$ & 39 \\
\hline \multicolumn{2}{|c|}{$\begin{array}{c}\text { Table 5: Mean Age at Presentation } \\
\text { of MNG in Various Studies }\end{array}$} \\
\hline
\end{tabular}

MNG is more common in women. The sex ratio varies as shown in Table 6.

\begin{tabular}{|c|c|}
\hline${\text { Ahuja et } \mathrm{al}^{31}}{ }^{23}$ & $3.76: 1$ \\
\hline Parija et al $^{32}$ & $4: 1$ \\
\hline Bhansali et al $^{32}$ & $3.2: 1$ \\
\hline Mathai et al $^{33}$ & $10: 1$ \\
\hline Ríos et al $^{34}$ & $11.2: 1$ \\
\hline Abu-Eshy et al $^{26}$ & $6.47: 1$ \\
\hline Bron and O'Brien $^{35}$ & $5.3: 1$ \\
\hline Delbridge et al $^{28}$ & $7: 1$ \\
\hline Present study & $3: 1$ \\
\hline Table 6: Sex Ratio of MNG in Various Studies \\
\hline
\end{tabular}

MNG is usually a long standing problem and it mostly presents as an asymptomatic swelling in front of the neck. Compressive symptoms occur commonly in long standing goitres. $^{34}$ Patients are mostly euthyroid. The mean duration of swelling is around 5 years as observed in various studies. In our study, the mean duration of swelling is 3.5 years.

FNAC is performed in MNG when there is a dominant nodule or there is suspicion of malignancy. 22 It is highly accurate and has given a confirmatory diagnosis in $92.5 \%$ of cases as correlated with histopathological examination. This is consistent with various studies. 
MNG is characterized by progressive thyroid growth. It can, owing to its anatomical location, expand to jeopardize neighbouring structures and lead to different compression symptoms. Most common are tracheal and oesophageal compression. ${ }^{34}$

MNG is occasionally associated with hyperthyroidism, sometimes transient episodes in up to $30 \%$ patients. ${ }^{36}$ The presence of hyperthyroidism in this study was not noted as all patients were taken up for surgeries only in the euthyroid state. Hypothyroidism is rare in MNG. Cohen-Kerem et $\mathrm{al}^{37}$ have noted in $2 \%$ and Ahuja et $\mathrm{al}^{31}$ in $5.6 \%$ of cases as compared to $0 \%$ in the present study.

Ríos et $\mathrm{al}^{34}$ have found out that family history of thyroid pathology had a role in development of MNG and in our study also we had 5 patients with a positive family history of thyroid pathology.

The surgical treatment of benign thyroid disease is still controversial, although many surgical subspecialties have developed, each have many angles and views. Many treatment modalities have been advocated for the surgical management of Multinodular goitre, i.e. total thyroidectomy, near total thyroidectomy, subtotal thyroidectomy, hemithyroidectomy, nevertheless clarity is missing regarding the safest and best option for the patients on a longer perspective. The indications for total thyroidectomy in the management of thyroid diseases are not well defined. The literature lists a few, like histories of head and neck irradiation, a Multinodular goitre grossly involving both the lobes, compressive symptoms and nodule with suspected malignancy. If the goitre is voluminous with compressive symptoms or if it is not possible to leave a grossly homogeneous thyroid remnant tissue because of location of possible nodules, total thyroidectomy is recommended. ${ }^{38}$ There is a growing evidence that total thyroidectomy is appropriate for patients with multinodular goitre where there is significant nodular disease involving both the lobes.28,39

Subtotal thyroidectomy may be the best elective procedure in older patients to avoid total and permanent dependence on drugs. Some authors favour the subtotal procedure because of its lower incidence of iatrogenic injuries, such as recurrent laryngeal nerve palsy and hypoparathyroidism..$^{40}$ Injury to the Recurrent Laryngeal Nerve (RLN) has a much greater impact and is more noticeable than superior laryngeal nerve injury. The incidence of permanent RLN palsy is approximately $01 \%$ to $01.5 \%$ for total thyroidectomy and less for near total procedures. Temporary dysfunction due to nerve traction occurs in $2.5 \%$ to $5 \%$ patients. ${ }^{41}$ The incidence of permanent RLN injuries after subtotal and total thyroidectomies varied from $0 \%$ to $01 \%$ and $0 \%$ to $1.3 \%$ respectively. ${ }^{42}$ In our study the incidence of superior and recurrent laryngeal nerve injury was $2.5 \%$, it seems to be more since the population size is less. As such only 1 patient had developed this complication out of 20 patients who underwent total thyroidectomy, whereas among the patients who underwent subtotal thyroidectomy there was no such complication occurred.

Normal parathyroid glands most commonly are supplied by a single dominant artery (80\%). ${ }^{43}$ In most instances, the superior and inferior parathyroid glands derive their dominant arterial blood supply from the inferior thyroid artery. Ligation of the inferior thyroid artery during surgery may not always compromise the blood supply to the superior parathyroid gland. Abundant arterial anastomoses exist between the parathyroid glands and include anastomoses with thyroid arteries and dominant arteries of the larynx, pharynx, oesophagus and trachea. Transient symptomatic hypocalcaemia after total thyroidectomy occurs in approximately $07 \%$ to $25 \%$ of cases, but permanent hypocalcaemia is less common ( $0.4 \%$ to $13.8 \%)$. In the present study, 1 patient out of 20 who underwent total thyroidectomy had developed hypothyroidism and hypoparathyroidism after surgery for a period of 3 months and among the patients who underwent subtotal thyroidectomy not even a single patient had developed this type of complication.

The goal of surgical treatment in MNG should be to eliminate the disease with a low complication rate and to minimize the necessity for reoperation because the risk of permanent complications has been found to be higher in reoperations for recurrent disease than in primary operations with extensive disease. If a surgeon leaves abnormal thyroid tissue in a patient with MNG, subsequent reoperation might be required. Recurrence develops in as many as $14.55 \%$ of cases after subtotal resection despite the prophylaxis; without suppressive therapy, the rate of recurrence increases to $43 \%{ }^{44}$ Ambrosi et al ${ }^{45}$ found that recurrence was inversely related to the extent of the resection.

Piraneo et $\mathrm{al}^{44}$ reported a 395 recurrence rate after enucleation, $27 \%$ after lobectomy, 20\% after lobectomy and contralateral enucleating excision and $04 \%$ after subtotal resection. Recurrence rates after subtotal thyroidectomy vary as much as $14 \%$. Ozbas et al ${ }^{13}$ reported administration of $\mathrm{L}$ Thyroxine in all cases of partial and total thyroidectomy in their study. The use of L-Thyroxine supplementation has been suggested to efficiently prevent recurrence. ${ }^{46}$ In our study, the recurrence was $15 \%$ at the end of 1 year follow-up among the patients who had undergone subtotal thyroidectomy and it was nil in patients who underwent total thyroidectomy.

Multinodular goitre is clinically important for several reasons. It may cause thyroid dysfunction or compressive symptoms, but it is even more important because of the need to exclude thyroid cancer. 47 The reported prevalence of malignancy in thyroid nodules, evaluated by biopsy, ranges from $4-6.5 \%$ and is largely independent of the nodule size. 48 Complications of thyroid surgery consist of temporary or permanent RLN palsy, temporary and permanent hypocalcaemia, haematoma and seroma. Due to ligation of all branches of vessels on superior and inferior pole, there were no patients in this study who required re-operation for haematoma.

The incidence of post-operative transient hypocalcaemia and transient RLN palsy were $2.5 \%$ and $2.5 \%$. No permanent complications and recurrence were shown. Some other studies had been accomplished to show the same results. Gal et $\mathrm{al}^{49}$ studied 264 cases underwent TT and the results showed 31 cases $(11.7 \%)$ with transient hypocalcaemia, but only 1 $(0.3 \%)$ symptomatic and only $4(1.5 \%)$ with permanent hypocalcaemia.

In a study of Veyseller et al,50 the incidence of postoperative permanent hypocalcaemia and permanent RLN palsy were $0.6 \%$ and $1.86 \%$, whereas we had no cases of these complications. Efremidou et $\mathrm{al}, 51$ showed the incidence of permanent RLN palsy as $0 \%$ and that of permanent unilateral RLN palsy as $0.2 \%$. Their results showed permanent hypocalcaemia in $0.3 \%$ and temporary hypocalcaemia in $7.3 \%$. In the present study only one case had hypocalcaemia and hypothyroidism in the patients who underwent total 
thyroidectomy and 3 patients had recurrence among the 20 who underwent subtotal thyroidectomy.

\section{CONCLUSION}

In total thyroidectomy, there is an increased risk in iatrogenic injuries. But when the frequency of complications in recurrent operations and the malignancy possibility of the thyroid tissue left behind (15\% in our study) are taken into consideration, we believe that despite the higher rate of post-operative complications TT will be more beneficial in the surgical treatment of benign thyroid disorders, especially those which are bilateral or extended to substernal space or which presented with compression symptoms.

\section{REFERENCES}

1. Stanbury JB, Ermans AM, Hetzel BS, et al. Endemic goitre and cretinism: public health, significance and prevention. WHO Chronicle 1974;28(5):220-228.

2. Delange F. Endemic goitre and thyroid function in central Africa. Monographs in Paediatrics 1974;2:1-171.

3. Gutekunst R, Scriba PC. Goitre and iodine deficiency in Europe: the ETA report as updated in 1988. Journal of Endocrinological Investigation 1989;12(3):209-215.

4. Ho Tw, Shaheen AA, Dixon E, et al. Utilization of thyroidectomy for benign disease in the United States: a 15-year population-based study. Am J Surg 2011;201(5):570-574.

5. Knudsen N, Perrild H, Christiansen E, et al. Thyroid structure and size and two-year follow-up of solitary cold thyroid nodules in an unselected population with borderline iodine deficiency. Eur J Endocrinol 2000;142(3):224-230.

6. Unnikrishnan AG, Kalra S, Baruah M, et al. Endocrine society of India management guidelines for patients with thyroid nodules: a position statement. Indian J Endocrinol Metab 2011;15(1):2-8.

7. Sheikh IA, Haider IZ, Waleem SS, et al. Total thyroidectomy as primary elective procedure in multinodular thyroid disease. J Ayub Med Coll Abbottabad 2009;21(4):57-59.

8. Gough IR, Wilkinson D. Total thyroidectomy for management of thyroid disease. World J Surg 2000;24(8):962-965.

9. Moalem J, Suh I, Duh QY. Treatment and prevention of recurrence of multinodular goitre: an evidence-based review of the literature. World J Surg 2008;32(7):13011312.

10. Olson SE, Starling J, Chen H. Symptomatic benign multinodular goitre: unilateral or bilateral thyroidectomy? Surgery 2007;142(4):458-461.

11. Agarwal G, Aggarwal V. Is total thyroidectomy the surgical procedure of choice for benign multinodular goitre? an evidence-based review. World J Surg 2008;32(7):1313-1324.

12. Vassiliou J, Tympa A, Arkadopoulos N, et al. Total thyroidectomy as the single surgical option for benign and malignant thyroid disease: a surgical challenge. Arch Med Sci 2013;9(1):74-78.

13. Ozbas S, Kocak S, Aydintug S, et al. Comparison of the complications of subtotal, near total and total thyroidectomy in the surgical management of multinodular goitre. Endocr J 2005;52(2):199-205.
14. Bauer PS, Murray S, Clark N, et al. Unilateral thyroidectomy for the treatment of benign multinodular goitre. J Surg Res 2013;184(1):514-518.

15. Colak T, Akca T, Kanik A, et al. Total versus subtotal thyroidectomy for the management of benign multinodular goitre in an endemic region. ANZ J Surg 2004;74(11):974-8.

16. Barczyński $M$, Konturek A, Stopa $M$, et al. Total thyroidectomy for benign thyroid disease: is it really worthwhile? Ann Surg 2011;254(5):724-730.

17. Friguglietti CU, Lin CS, Kulcsar MA. Total thyroidectomy for benign thyroid disease. Laryngoscope 2003;113(10):1820-1826.

18. Barczyński M, Konturek A, Hubalewska-Dydejczyk A, et al. Five-year follow-up of a randomized clinical trial of total thyroidectomy versus Dunhill operation versus bilateral subtotal thyroidectomy for multinodular nontoxic goitre. World J Surg 2010;34(6):1203-1213.

19. Bakiri F, Hassaïm M, Bourouba MS. Subtotal thyroidectomy for benign multinodular goitre: a 6month postoperative study of the remnant's function and sonographic aspect. World J Surg 2006;30(6):10961099.

20. Tezelman S, Borucu I, Senyurek-Giles Y, et al. The change in surgical practice from subtotal to near-total or total thyroidectomy in the treatment of patients with benign multinodular goitre. World J Surg 2009;33(3):400-405.

21. Thompson NW, Olsen WR, Hoffman GL. The continuing development of the technique of thyroidectomy. Surgery 1973;73(6):913-927.

22. Day TA, Chu A, Hoang KG. Multinodular goitre. Otolaryngol Clin North Am 2003;36(1):35-54.

23. Parija BL, Panda RS, Samal KK, et al. Clinicopathological study of goitre in south Orissa. Indian Pract 1997;50:840-845.

24. Chellum VG, Verghese S, Mathew KT. A study of thyroid disorders in south Kerala. Indian J Surg 1981;43:10-16.

25. Osime U. Goitre: a review of 150 patients undergoing thyroidectomy at the university of Benin teaching hospital, Nigeria during 1973-1980. Indian J Surg 1984;46:41-45.

26. Abu-Eshy SA, Khan AR, Khan GM, et al. Thyroid malignancy in multinodular goitre and solitary nodule. J R Coll Surg Edinb 1995;40(5):310-312.

27. Koh KB, Chang KW. Carcinoma in multinodular goitre. $\mathrm{Br}$ J Surg 1992;79(3):266-267.

28. Delbridge L, Guinea AI, Reeve TS. Total thyroidectomy for bilateral benign multinodular goitre: effect of changing practice. Arch Surg 1999;134(12):1389-1393.

29. Korun N, Asci C, Yilmazlar T, et al. Total thyroidectomy or lobectomy in benign nodular disease of the thyroid: changing trends in surgery. Int Surg 1997;82(4):417419.

30. Marchesi M, Biffoni M, Tartaglia F, et al. Total versus subtotal thyroidectomy in the management of multinodular goitre. Int Surg 1998;83(3):202-204.

31. Ahuja MM, Kumar V, Malhotra KK, et al. Profile of nodular goitre. J Assoc Physicians India 1968;16(10):699-707.

32. Bhansali SK, Satoskar RS, Bijlani JC, et al. Some facets of nontoxic goitre: an appraisal of 884 cases. Indian J Surg 1973;35:473-479. 
33. Mathai V, Idikula J, Fenn AS, et al. Do long-standing nodular goitres result in malignancies? Aust N Z J Surg 1994;64(3):180-182.

34. Ríos A, Rodríguez JM, Canteras M, et al. Risk factors for malignancy in multinodular goitres. Eur J Surg Oncol 2004;30(1):58-62.

35. Bron LP, O'Brien CJ. Total thyroidectomy for clinically benign disease of the thyroid gland. $\mathrm{Br} \mathrm{J}$ Surg 2004;91(5):569-574.

36. Krukowski ZH. The thyroid and the thyroglossal tract. In: Russell RC, Williams NS, Bulstrode CJ, eds. Bailey and love's short practice of surgery. London: Arnold 2004;24th edn:p.776-803.

37. Cohen-Kerem R, Schachter P, Sheinfeld $M$, et al. Multinodular goitre: the surgical procedure of choice. Otolaryngol Head Neck Surg 2000;122(6):848-850.

38. Ngan ES, Lang BH, Liu T, et al. A germline mutation (A339V) in thyroid transcription factor-1 (TITF-1/NKX2. 1) in patients with multinodular goitre and papillary thyroid carcinoma. J Natl Cancer Inst 2009;101(3):162175.

39. Pelizzo MR, Bernante P, Toniato A, et al. Frequency of thyroid carcinoma in a recent series of 539 consecutive thyroidectomies for multinodular goitre. Tumori 1997;83(3):653-655.

40. Foster RS. Morbidity and mortality after thyroidectomy. Surg Gynaecol Obstet 1978;146(3):423-429.

41. Lore J, Kim DJ, Elias S. Preservation of the laryngeal nerves during total thyroid lobectomy. Ann Otol Rhinol Laryngol 1977;86(6 Pt 1):777-788.

42. Perzik S. The place of total thyroidectomy in the management of 909 patients with thyroid disease. Am J Surg 1976;132(4):480-483.

43. Delattre JF. Les variations des parathyroïdes. Nombre 2, situation et vascularization artérielle. Étude anatomique et applications chirurgicales. Paris: J Chir 1982;199:633.
44. Piraneo S, Vitri P, Galimberti A, et al. Ultrasonographic surveillance after surgery for euthyroid goitre in patients treated or not treated with thyroxin. Eur J Surg 1997;163(1):21-26.

45. Ambrosi A, Pezzolla A, Barone G, et al. Studio clinico della funzione residua edelle recidive in pazienti operati di tiroidectomie parziali per struma nodulare eutiroideo.Ann Ital Chir 1994;65:543-547.

46. Bistrup C, Nielsen JD, Gregersen G, et al. Preventive effect of levothyroxine in patients operated for non-toxic goitre: a randomized trial of one hundred patients with nine years follow-up. Clin Endocrinol (Oxf) 1994;40(3):323-327.

47. Hanumanthappa MB, Gopinthan S, Rithin S, et al. The incidence of malignancy in multi-nodular goitre: a prospective study at a tertiary academic center. J Clin Diagn Res 2012;6(2):267-270.

48. Lin JD, Chao TC, Huang BY, et al. Thyroid cancer in the thyroid nodules evaluated by ultrasonography and fineneedle aspiration cytology. Thyroid 2005;15(7):708717.

49. Gál I, Solymosi T, Lukács-Tóth G, et al. The efficacy and safety of total thyroidectomy in the management of benign multinodular goitres. Magy Seb 2013;66(5):245249.

50. Veyseller B, Aksoy F, Demirhan H, et al. Total thyroidectomy in benign thyroid diseases. Kulak Burun Bogaz Ihtis Derg 2009;19(6):299-303.

51. Efremidou EI, Papageorgiou MS, Liratzopoulos N, et al. The efficacy and safety of total thyroidectomy in the management of benign thyroid disease: a review of 932 cases. Can J Surg 2009;52(1):39-44. 